\title{
Street Food Vending as a Public Health Intervention
}

\author{
Kaniyaa Francis and Catherine Brinkley \\ Department of Human Ecology, College of Agriculture and Environmental Sciences, \\ University of California, Davis
}

\begin{abstract}
Background and Purpose: Disparities in access to healthy food can be partially alleviated by street food vending. This research aims to inform broader policies about healthy food access by focusing on the overlooked potential of street food vending. Methods: To reveal the spatiality and contents of street food vending regulations across Californian cities and counties, we reviewed municipal codes for all 58 counties and 213 cities in California. Recent legislation (SB 946, 2018) mandates that ordinances cannot regulate street food vendors for reasons beyond public health concerns. Results: We found that the majority of California cities and counties are out of compliance and will need to update regulations. The majority of California cities (85\% of those reviewed) and counties (75\%) include street food vending regulations that go beyond public health rationale and include labor laws and restrictions on time and hours of operation. Previous studies have noted that such restrictions negatively impact the health of street food vendors while also potentially jeopardizing the health vending customers. Conclusion: This research highlights the need for policy change, and notes that broader legalization of street food vending offers a unique opportunity to reassess the associated health benefits reviewed in prior literature.
\end{abstract}

(C) 2020 and CC-BY 4.0 licensed by the authors.

Keywords: informal economy, food policy, diet-related health, city planning, diet, food insecurity, fruits and vegetables

\section{Introduction}

A broad literature has documented the increasing disparity in healthy food access for low-income communities, with preventable dietrelated diseases that were once considered "adult-onset" now affecting youth (Lucan, 2015). There are quantified multi-generational health outcomes associated with a poor diet, including high incidence of obesity, hypertension and diabetes than can impact pregnant women and children (Murray et al., 2013). Motivated by these findings, city councils, federal agencies, and public health advocates have proposed and implemented numerous responses. Often such efforts require large inputs of capital or land, for example in establishing new supermarkets in underserved neighborhoods (Brinkley et al., 2017 and 2019).
Recently, researchers have noted that smallscale mobile retailers such as farmers' markets, produce trucks and healthy street food offer locally owned, culturally relevant, cost-effective healthy food access in many parts of the world (Yasmeen, 2001; Brinkley et al., 2017). Street food vendors do not require real estate, need little start-up funding, and can easily target schools and neighborhoods with poor access to healthful foods. Policies to encourage healthy street food vending present a public health intervention approach that is low-cost and builds upon already existing vending practices in many low-income communities.

The practice of street food vending is on the rise globally with an estimated 2.5 billion people around the world eating street food every day 
(Abrahale et al., 2019). Nationwide, revenue for food trucks alone increased by $9.3 \%$ from 2010 to 2015 , with an estimate of $\$ 1$ billion in sales in 2019 (IBIS, 2019). This figure is an underestimate and does not include street vending sales from pushcarts and pop-up stands. In Los Angeles, an estimated 10,000 to 50,000 street vendors generate approximately $\$ 504$ million in sales annually (The Economic Roundtable n.d). The figures are likely to continue to increase according to a nationwide survey that finds that people have positive feelings for food trucks that spur future shopping habits (Shin et al., 2018).

The rise in street food vending, combined with its potential to provide healthy food options, are prompting many cities and counties to revise their street food vending regulations. In addition, California recently (September 2018) legalized street food vending with Senate Bill 946. Passage of this bill mandates that California municipalities cannot determine where vendors can operate unless there is a health, safety, or welfare concern, nor can municipalities require permission from adjacent businesses to operate. Nevertheless, many cities and counties have existing code that restricts vending based on locations of operation, times of operation, and labor laws that go beyond those required in other food sectors. For example, some cities place time limits such that vendors cannot stop for more than five or ten minutes. Such restrictions effectively ban the practice of street food vending. Very limited public health research has addressed this topic. Hence, there is little guidance for practitioners to draw from in revising ordinances. This research gap may cause public officials, advocates, and researchers to overlook an effective approach to improve neighborhood health or make poor recommendations.

\section{Background}

To begin, we provide an overview of governance and the public health consequences. It is important to note that there are many different types of street food vending in terms of ownership, vehicle design, products sold, volume sold, and preparation. Vendors may act singularly or as part of an association or franchise (Weber, 2012; Esparza et al., 2014). Vendors sell from a variety of mobile designs: pushcarts, bicycle carts, display stands, food trucks, temporary refrigerated box trucks, and stationary box trucks, each necessitating design oversight as part of inspections to ensure proper cooling, ventilation and sanitation. The semantics vary in describing styles of vending and associated neighborhood culture. In San Diego, California, vendors use paleteros (pushcarts) to sell cut fruit (Calderon, 2015). In Oakland, California vendors are called fruteros (mobile fruit vendors), and typically sell bags of precut $1 / 2$ cup servings of fruits and vegetables (Tester et al., 2012). In West Philadelphia, Pennsylvania, vendors sell whole fruits and vegetables from the backs of stationary box trucks (Brinkley et al., 2013). In Baltimore, African American vendors, called Arabbers, sell fresh whole fruit and vegetables from horseback (Rubinstein, 2018). In Troy, New York the Veggie Mobile is a nonprofit-run refrigerated box truck that travels to low-income areas and sells low-cost fruits and vegetables (AbuSabha et al., 2011). Vending styles influence not only the legitimatization and permitting of a mobile vendor, but also the acceptability of the vendor in neighborhoods of varying socioeconomic classes and cultures.

\section{Positive Diet-related Health Impacts}

Studies from North America recognize that street food may have positive diet-related impacts compared to other sources of food. Five US-based studies assessed corollaries to dietrelated health, with the most common finding of increased produce intake for shoppers who buy from street food vendors (AbuSabha et al., 2011; Tester et al., 2012; Li et al., 2014; Zepeda et al., 2014; Breck et al., 2015). Focus groups conducted in cities in Washington, Illinois, Wisconsin, and Washington DC showed that those who shopped at mobile markets consumed an average of 1.5 more servings of fruits and 
vegetables per day than non-shoppers (Zepeda et al., 2014). Brinkley et al. (2013) found that curbside vendors offer statistically significant lower prices and similar produce variety when compared to the closest supermarkets in the area. Vendors also positively influenced the food environment. The presence of vendors selling fruits and veggies was found to decrease the presence of competing vendors selling nonnutritious food over the course of a fourteen-day study in Oakland, California on fruteros (Tester et al., 2012). Li et al. (2014) found that the presence of street food vendors may increase overall fruits and vegetable accessibility by lowering prices through competition and increasing the visibility of fresh produce. Further, Holmes et al. (2018) interviewed 33 food trucks in Toronto, Canada- finding that food trucks emphasized buying from local businesses, buying fresh food from farms within the province, and $60 \%$ of the trucks purchased organic ingredients with the primary source being local suppliers and farms.

Reasons for such positive findings regarding the purchasing of healthy foods include the affordability of the produce sold, cultural relevance of the offerings, and sales compatibility with Supplemental Nutrition Assistance Program (SNAP) and Electronic Benefit Transfer (EBT). While not all vendors are equipped with EBT machines because of the costs associated with them, vendors who have EBT report SNAP redemption as important to their business model, indicating that street food caters to low-income communities and is wellsuited to promote healthy food purchasing habits (Brinkley et al., 2013). Customers who use SNAP benefits are also more likely to shop at street vendors than any other produce source and spend an average of $\$ 3.86$ more on fruits and vegetables than customers who pay with cash (Breck et al., 2015).

In recognition of the potential positive impacts of street vending on diet-related health, many cities are piloting interventions. In some cases, legalizing an existing practice is the intervention. For example, Chicago's Public Health Department legalized independent produce vendors selling fresh fruits, veggies, and nuts as part of a 'Neighborhood Carts' program provided that at least $50 \%$ of produce carts operate in designated underserved areas (Wright \& Anderson, 2014). Similarly, New York's 2008 'Green Cart' initiative created 1,000 permits for street food vendors to operate in areas where at least $14 \%$ of residents said they had not eaten any fruits and vegetables the previous day (Lucan et al., 2011; Leggat et al., 2012; Breck et al., 2015). In 2010, in order to increase the effectiveness, the New York State Department of Health covered the $\$ 900$ cost of an EBT machine and the first three months of fees for eligible vendors (Breck et al., 2015). Two themes emerge across studies assessing street food a healthy food intervention. First, street food vending increases the accessibility to and consumption of fresh fruits and vegetables. Second, city and county-level permit and license requirements are significant barriers to entry.

\section{Regulation of Street Food}

Street food is subject to overlapping municipal and state regulations (see Table 1). Ordinances pertaining to food safety are typically state level. In California, the California Retail Food Code applies to street food vending operations as well as fixed retail food facilities (Vanschaik and Tuttle, 2014). The primary focus of state-level food safety regulations is on food-handling practices that influence contamination. Statelevel taxes on food to-go depend on a complex assessment of the meal (breakfast, lunch, dinner), if the food is heated, and what the contents of the prepared food include (Eskenazi, 2012). Beyond these state regulations, vendors are licensed, permitted and inspected at the local county or city level annually (Vanschaik and Tuttle, 2014). Regulatory environments vary widely between municipalities (Esparza et al., 2014; Meneses-Reyes, 2018) particularly around zoning regulations that govern suitable locations and times of operation. 


\section{Food Safety}

The World Health Organization's (1996) international call to increase the safety of food sold on the street, notes that there are multiple points for contamination in the food production chain during transport of products to the vending site, and the preparation of mixed ingredients, as well as cooking, storing, serving, sanitizing and waste management practices. As a result, street food vendors operate with comparable food safety risk compared to fixed retail establishments (Donkor et al., 2009; Auad et al., 2018; Valente et al., 2019). In a review of critical food safety risk factors in 95 food trucks in California, Vanschaik and Tuttle (2014) found that mobile food trucks exhibit risk attributes that are statistically comparable to fixed food facilities.

Research, however, often overly emphasizes food safety risks in street food. For example, Ababio and Lovatt, (2015) reviewed food safety studies in Ghana and found that most food safety research focused exclusively on street foods with limited information on other sources of food, such as institutional catering or school food that have a greater reach in clientele and potential for larger food-borne outbreaks. The bias in the research focus is further amplified as many studies on street food use small sample sizes (e.g., Campos et al., 2015; Kothe et al., 2016). In addition, hundreds of studies have assessed food contamination, but rarely other health considerations such as street food availability, cost, eating habits or nutritional content (Abrahale et al., 2019). The consumption of street-food is common especially where unemployment is high, wages are low, job opportunities and social programs are limited (Yasmeen, 2001; Meneses-Reyes, 2018), so added scrutiny has the effect of urging an increase in policing of low-income neighborhoods. Last, most research on street food vending has been conducted in the global south and provides a rich context to draw upon (Devlin, 2018), but generates some bias in translation as food safety regulations differ from county-to-county.

\section{City and County Regulations: Enforcement,} Inspections and Cost

The state governs food safety, but cities and counties are responsible for enforcing and inspecting (Table 1). Though food safety and fire inspectors routinely visit brick and mortar facilities for inspection, locating street food vendors can add to the time and costs of inspections (Vanschaik \& Tuttle, 2014). To support the costs of inspection, many cities charge for permits to vend, with increased costs for licenses to operate in certain jurisdictions or during certain times. Often cities also use permitting caps to curtail the number of vendors, the number of vendors per location, and the types of vending by vehicle or good.

In a state-level review of street food safety regulations in Florida, Okumus and Sonmez (2019) note that the costs of regulations can sometimes be too high for low-income street food vendors and their clients, resulting in unlicensed operations that lack public health oversight. Such findings indicate that license and permit pricing needs to be carefully weighed against economic realities, particularly in lowincome neighborhoods where the cost of permits and actions required to satisfy permitting are at odds with the cost of doing business. For example, City Heights, San Diego, a low income, immigrant community, charges $\$ 5,427$ for two required permits (Calderon, 2015). 
Table 1.

Common Regulations Governing Street Food Vending and their Governmental Level of Enforcement

\begin{tabular}{|c|c|}
\hline Code & Description \\
\hline \multicolumn{2}{|r|}{ STATE } \\
\hline $\begin{array}{l}\text { California State } \\
\text { Vehicle Code }\end{array}$ & $\begin{array}{l}\text { Governs the design of the vehicle and state equipment requirements for food } \\
\text { preparation equipment in mobile food vending vehicles. Must comply with this code } \\
\text { to obtain a state vehicle license. }\end{array}$ \\
\hline $\begin{array}{l}\text { California Health } \\
\text { and Safety Code }\end{array}$ & $\begin{array}{l}\text { State food safety codes govern to food handling, storage, processing, personnel and } \\
\text { equipment hygiene }\end{array}$ \\
\hline Driver's license & Required by each vehicle driver (unless a bicycle or pushcart is used) \\
\hline
\end{tabular}
COUNTY

County Food

Vending

Inspection
Annual permitting. Inspection enforces codes in California Health and Safety Code. On-site inspections are encouraged. Health certificate should be clearly displayed for clientele.

\section{CITY}

Vendors can only sell in locations that are not more than $200 \mathrm{ft}$ from public toilet and handwashing facilities in accordance with California Health and Safety Code; vendors

Zoning restrictions shall keep customers and other patrons from blocking all streets, sidewalks, paths, driveways, doorways, and other avenues of vehicular and pedestrian traffic. No operating within $50 \mathrm{ft}$ of intersection.

Food Safety

Food vending vehicle driver permit Comply with county regulations, display safety permits and licenses for customers. Inspected by city.

Annual application, must have valid driver's license, pushcart and bicycle-driven food carts need not apply.

Annual application to operate in stationary location. Must prove ownership of property

Food vending vehicle property permit

Vehicle Permit

Business operations tax

Required insurance policies

Violations or owner consent and post notice to neighbors of intent to operate food vending. City Inspector will visit site and may refer police department to understand the noise and nuisance implications for the neighborhood. If two or more food trucks are to be located on the property, the owner must apply for the Conditional Use Permit for a food market issued pursuant to the city's Planning and Development Code Annual. All vendors must have valid city business operations tax certificate, proof of compliance with the insurance requirements, evidence of vehicle ownership, proof of compliance with county food vending vehicle inspections and design. City official will also inspect the vehicle to assure that the vehicle complies with the State Vehicle Code Requirement. Decal must be visibly displayed. Vehicles that are not bikes or pushcarts must have a state vehicle license plate number and valid driver's license.

City-level tax on businesses

Commercial and general liability insurance, including products and completed operation coverage, during the term of the vehicle permit; comprehensive auto liability insurance

Criminal sanctions, civil actions, administrative penalties, and fines 
In order to apply for some city and county licenses one must have a social security number, making it impossible for undocumented immigrants to sell legally (Calderon, 2015). Cities will also often require fingerprinting, interviews with the sheriff and letters of good moral standing. Because mobile food vendors are often low-income immigrants and people of color (Martin, 2014; Meneses-Reyes, 2018), these policies are intimidating barriers to entry and encourage informality of an already marginalized group. Vendors have reported accidental burns due to distraction, as they maintain a lookout for patrolling police officers (Calderon, 2016). Empirical evidence shows street food vendors are at greater risk of being victimized and criminalized by the public than the general population (Pick et al., 2002; Brata, 2008; Benach et al., 2007; Brown 2015; Roever, 2016).

Municipal city and county regulations also designate where in the city vendors can locate and during what hours through zoning regulations. Ehrenfeucht (2016) reviewed three U.S. cities regulations and finds the rationale for regulations is to protect property interests, prevent traffic congestion, and keep the street orderly. The last two rationales have a direct link to public health. Further, Ehrenfeucht (2016) found no sidewalk crowding due to food trucks. The assumption that more street vending or stationary activity causes significant delays for pedestrians is unsubstantiated. Other scholars have noted that harassment by abutting businesses determines how and where vendors operate as much as specific regulations (Devlin 2011; Kettles, 2004).

\section{Advocacy and Changes to Regulation}

The power dynamics and interplay with national and city-level economic fortunes is important to understanding how to public health officials can craft street food regulations that help communities equitably weather economic downturns. As the presence of street food, and food trucks in particular, has increased since the 2008 recession (Esparza et al., 2014), many cities began altering or more heavily enforcing regulations. For example, in Chicago, vending from food trucks was legalized in 2012- after lobbying by two chefs, but other forms of street food are not legal (Martin, 2014), creating inequality across vending regulations and the neighborhoods they serve.

Esparza et al. (2014) reviewed regulations for 11 U.S. cities from 2009 onward, noting that restrictive regulations were often created at the behest of brick-and-mortar restaurants, who have well-established trade associations that lobby the local and state government for protection against competition. Conversely, Liu et al. (2015) reviewed the location of street vendors and brick and mortar establishments in Los Angeles over the economic recession and found that locations with greater sidewalk vending experienced a protective effect with growth of brick and mortar retail, presumably as a result of lively sidewalk economies and sustained foot traffic. In support, research from farmers' markets shows that pop-up retail can increase purchases from nearby businesses (Brown \& Miller, 2008).

In response to changes in city regulations and hostility from brick and mortar restaurant associations, street food vendors have also formed advocacy associations (Linnekin et al., 2012; Esparza et a., 2014). The focus of many efforts is on lifting restrictive zoning over times and proximity bans. The New York City Food Truck Association (NYCFTA) lists lifting the permit cap on the number of mobile venders as their top reform priority (Esparza et al., 2014). The Washington D.C. Food Truck Association's (DCFTA) priority is to reform time limits on how long vendors can operate in one location. The "ice cream truck" or "stop and wait" rule allows vendors to vend only when hailed by a customer (Esparza et al., 2014).

Perhaps most telling of enforcement emphasis and infraction, street food vendors are more frequently cited for violations of zoning 
ordinances, not food safety. Q'adri (2017) mapped 97,773 vending violations over a fiveyear period in Manhattan, New York. The most common violations, a quarter of the total, resulted from vending within $10 \mathrm{ft}$ of a restricted area. Violations for time ordinances were 14\% of the total, while only 5\% resulted from vending without permit or license (Q'adri, 2017). Less than $2 \%$ of citations were for a health code violation $(n=1760$ violations over a 5-year period, Q'adri, 2017). These findings note that city-level regulations and enforcement should be reconsidered in light of a holistic view of public health.

\section{The Present Study}

This study provides background on the potential of street food vending as a public health intervention and its regulatory barriers to expansion. We first frame key policy issues and public health concerns about street food. Literature helps inform public health-relevant topics for our survey of municipal code. Next, by geographically mapping policy governing street food vending in the State of California, USA, we demonstrate the breadth and range of policy approaches. Our focus on California allows this research to further timely policyrelevant dialogs.

\section{Methods}

To explore the variation in city and county-level street food regulations and better understand policy barriers, we gathered municipal ordinances in California, the most populous state in the US with nearly 40 million people living in diverse settings from some of the world's wealthiest cities to low-income neighborhoods, urban to rural, and coastlines to mountains.

First, we queried the publicly available Municode library for California municipalities using the search terms: food, vendor, peddling/peddler, cart, vegetable, and fruit. Municode.com is the largest digital publisher of municipal codes, containing codes from 2,700 cities and counties in all 50 states (Municode,
2014), ensuring replicability beyond this study. Cities are not required to house their codes on municode, and nor do all cities use this search engine. As a result, street vending ordinances were gathered for 213 of the 485 California cities. Where the Municode database did not cover counties, we queried county websites for code in order to assemble a complete code database for all 58 California counties. The entire code section pertaining to street food was read and hand-coded based on allowance or prohibition of street food vending, land use restrictions, labor requirements, and time restrictions. We noted the date that the ordinance was passed or modified. We mapped results using ArcGIS and GeoDA.

\section{Results: Municipal Code Review}

Data from 213 cities and all 58 counties in California shows that the majority of cities $(85 \%$ of those reviewed) and counties (75\%) include street food vending regulations that go beyond public health rationale and include labor laws and restrictions on time and hours of operation. We reviewed $44 \%$ of California's 485 city regulations, finding that only $15 \%$ of those reviewed (33 cities) allow street food vending without restrictions in the municipal code. Comparatively, counties are less restrictive than cities in regulating street food vending with a quarter of the counties (24 counties) allowing the practice without time, labor or land-use restrictions. Only eight of California's 58 counties (14\%) did not list street food regulations and six $(10 \%)$ referred only to business permits and public health codes but did not place further restrictions.

While more rural counties in northern and eastern California tended to have fewer restrictions on street food vending (Figure 1), cities were more varied. Larger cities had reduced restrictions on labor laws, but more closely regulated times of operation and location. Presumably, complicated urban economic politics generated more focus on 
limiting where vendors locate and at what times of day.

Most cities and counties required vendors to apply for (and display) city permits. Yet, only sixty-three cities and thirteen counties linked city permits to public health offices in their municipal code, thereby calling attention to requirements for a public health official to inspect vendors' vehicles and make sure that they followed the current health standards. Thus, restrictions for street food vending focus less on public health and more on regulating operation time, location and vending operators.

\section{Time Restrictions}

The most common restriction at the city level was restriction of operating hours. Over $65 \%$ of the cities reviewed $(n=139)$ allow vending with time restrictions (Figure 1). Time restrictions were imposed in 21 counties $(36 \%)$. The most common time limit required vendors to stop no longer than 10 minutes; however, the restriction ranged from 5 minutes to 12 hours. If a food truck cannot stop of more than 10 minutes, the vendor cannot prepare and wrap the food, nor deliver food to a line of customers. Such restrictions effectively ban the practice of street food vending.

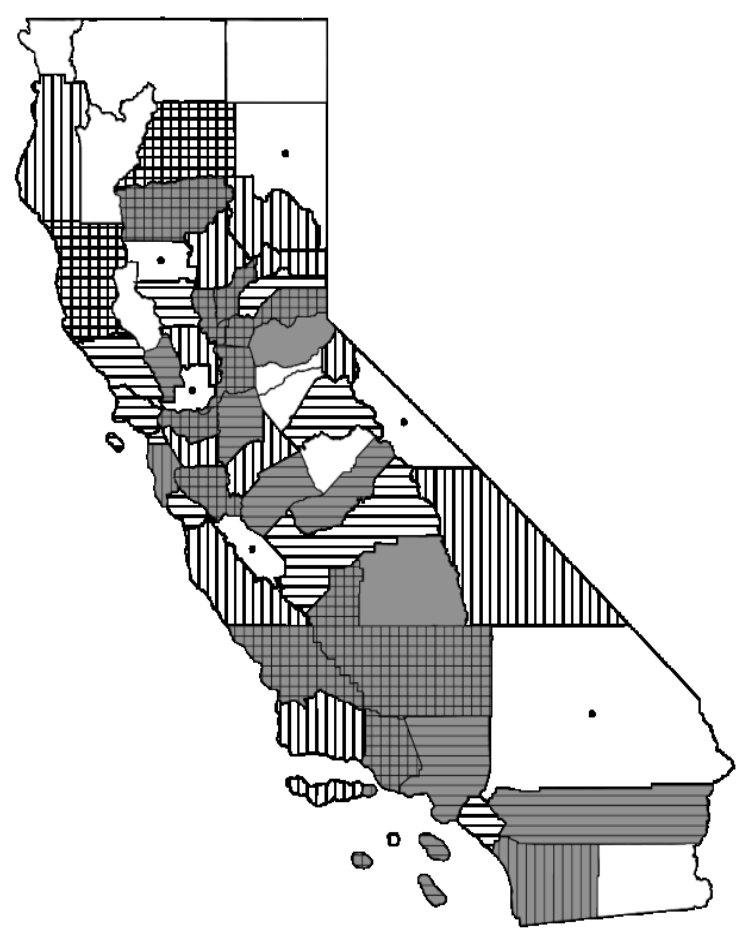

- Regulations without restrictions

Allowed with labor restrictions

Allowed with land restrictions

Allowed with time restrictions

No regulations

Figure 1. Map of county-level street food vending restrictions. 


\section{Land-use Restrictions}

At the county-level, the most common form of street food regulation is on land-use. Nearly half of California's counties $(n=28$, Figure 2) imposed land-use restrictions. The second most common restrictions in cities were spatial $(54 \%$ of cities reviewed, 116 cities). This difference in emphasis between cities and counties is presumably because counties are larger in territory, more rural, and would focus more on spatial aspects. For example, 73 cities and 5 counties prohibited or restricted vending near schools and 36 cities and 4 counties restricted vending in public parks. The new state-level SB946 regulation expressly prohibits local regulations from banning vending in public parks.
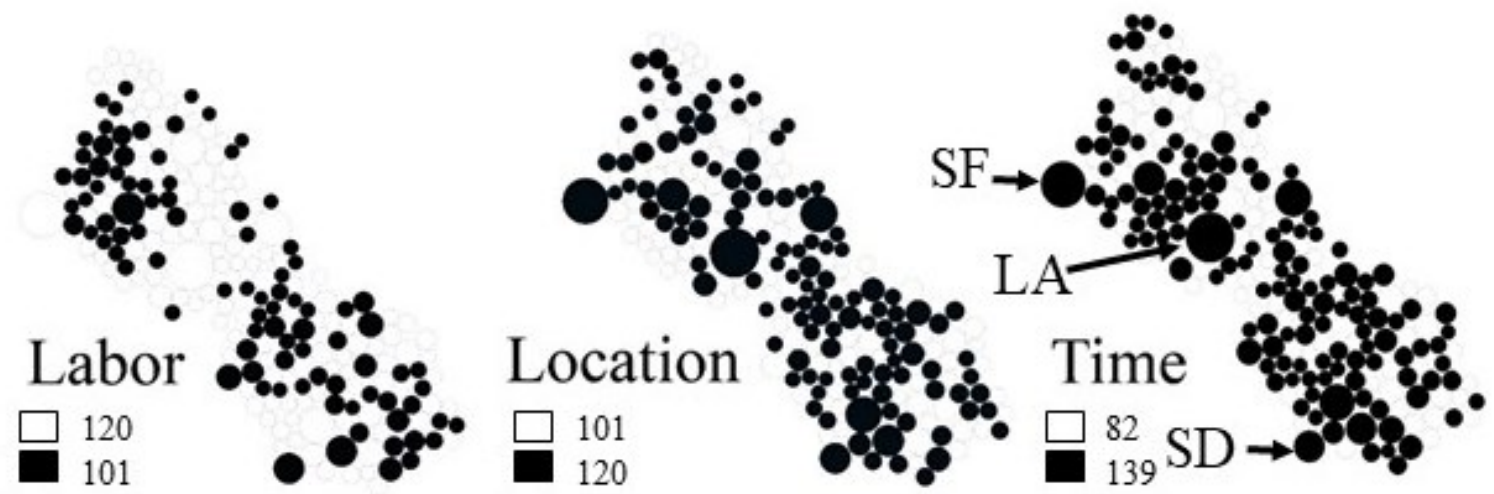

Figure 2. Bubble map of city-level street food vending regulation where bubble size correlates to city population, and dark shading indicates restrictions on labor, location or time. Large cities are labelled for spatial reference: San Francisco (SF), Los Angeles (LA), and San Diego (SD)

\section{Labor Restrictions}

Labor restrictions were prevalent in cities (43\%, 91 cities) and counties ( 25 counties, 43\%). Many of cities and counties had legislation in place to prohibit undocumented individuals from operating mobile food facilities. For example, sixteen cities required a Social Security number to be listed on the application, making it impossible for undocumented workers to legally operate. Additionally, 68 cities and 18 counties required criminal background checks and fingerprinting upon submission of the permit application. For example, Butte County requires all vendors to register with the sheriff's office and supply: name; address; personal description, nature of business; name and address of employer or supplier of goods to be sold; duration of solicitation; prior felony convictions, if any. Following registration, "the sheriff shall photograph and fingerprint the applicant and make an investigation concerning the character of the applicant." While Butte County's code was created in 1952, Sutter County created a similar code in 2004 requiring prospective vendors to undergo an "investigation [by the sheriff] showing that the applicant is of good moral character and has not been convicted of any felony or of any crime of moral turpitude and has made no false statement on the application" (Ord. 1378, Sec. 2; Feb. 17, 2004). Comparatively, restaurant owners were not required to have background checks in either county. Cities had similar discriminatory codes. The City of Sacramento's code was updated in 2019 and requires that applicants for the city vending permit disclose any physical or mental conditions and medications taken that could interfere with vehicle management. Moreover, 
14 cities and one county prohibited pushcarts and human-powered devices, the vending vehicle most often used by immigrant farmers. Yet, these sites allowed food trucks, demonstrating discrepancies in public health regulations along the lines of socioeconomic status.

\section{Policy Innovations}

While rare, a few cases provide insight into policy innovation around street food vending. For example, Yolo County has reciprocity with Sacramento County, allowing vendors to undergo inspection in one county or the other. Such policies help ease the burden of regulation and associated fees on vendors that operate in multiple counties, while also reducing the workload for public health officials. Moreover, Yolo County issues permits via email, reducing time and paperwork for vendors while also allowing a rapid system for outreach. In an effort to add 'green' vending options, the City of Sacramento code was amended in October 2018 to add bicycles and pushcarts operating as food vending vehicles (5.68.025). The City of Sacramento's code also requires vendors to comply with parking limits like other traffic, thereby limiting parking concerns while ensuring public safety through already existing traffic control ordinances. Where food trucks partner with restaurants and comply with parking, they can stay longer than the 2-hour limit imposed by the State because they would have access to a bathroom and warm water. This feature helps improve the occupational health of street food vendors.

\section{Discussion: Public Health Implications}

Few empirical studies detail the scope of street food regulations, though scholars and policymakers argue that understanding the scope of such licensing is essential for guaranteeing a place to work for the urban poor (Roever 2016; Meneses-Reyes 2013) and generating revenue for local governments (Davy, 2009; Brown, 2015; Webster, 2015; Roever; 2016). Because so many studies on street food vending are in lowincome countries and places - they may overstate the risk of food borne illness, helping to feed the literature with more cause to ban than allow and inspect street food. As both formal and informal street vending practices expand, a more holistic view of the public health implications is needed to guide policymakers and inform researchers, particularly given the politically charged lobbying that influences the creation and enforcement of regulations.

\section{Identifying Impediments}

To this end, results show that the majority of California's surveyed cities and counties place restrictions on street food vending that go beyond public health considerations and may exacerbate health disparities or produce negative health outcomes. The high cost of regulations, limited business times, restrictions on locations near highly trafficked areas, and requirements for criminal background checks and social security numbers are all impediments to the street food vending model. Such restrictions may effectively ban the practice if vendors are not able to access enough clientele to make a profit from their business. Restrictions on street food vending were common in urban areas, where street food vending is particularly well adapted as both a means of earning a living and in serving low-income consumers. This research is the first to show the widespread extent of prohibitory ordinances.

\section{Removing Impediments}

In order to comply with SB46, many California cities and counties will need to change their regulations as indicated in Figures 1 and 2 . Indeed, the most populous counties and cities in California have regulations that restrict street food vending beyond the scope of public health concerns. For some cities, the policy intervention may be as simple as removing a time restriction. For others, easing location restrictions would broaden the populations mobile vendors can reach and could create new economic opportunities as well as improving health. For example, Portland, Oregon's landuse code allows zoning of city blocks to provide permanent space to food trucks with outdoor 
eating. There, the street food scene is an economic development tool that draws foot traffic toward new commercial districts. Table 1 provides a guide for common state, county and city regulations governing street food vending. Policymakers would do well to critically review their local street food vending ordinances in light of public health concerns for customers, vendors, and neighborhoods.

Overly restrictive street food vending ordinances are detrimental to public health by virtue of spurring the informal economy, resulting in occupational health issues as vendors become more vulnerable to exploitation and violence. For example, storeowners have employed nuisance laws to harass vendors to repeatedly show their required permits (Calderon, 2016, Brinkley et al., 2013). Vendors are also often restricted from selling in places with public bathrooms, such as public parks, leading to few bathroom breaks and dehydration (Calderon et al., 2016). Revising street food vending ordinances in light of the evidence-based studies can improve health outcomes for vendors and their clients. For example, removing the necessity of a social security number when applying for a business license would allow undocumented immigrants to sell food legally, reducing the risk they face while potentially increasing the availability of low-cost, culturally relevant healthy food.

\section{Innovating with Vending Ordinances}

Removing restrictions allows the practice of street food vending to emerge, but our review of street food vending codes also points to places where local jurisdictions can innovate or save costs while improving public health. For example, expanding ordinances to allow pushcarts and vending from bicycles could extend the reach of healthy food options and decrease fumes, greenhouse gas emissions and noise associated with vending from vehicles. Further, county-to-county reciprocity agreements for inspections can cut costs for vendors who operate over several jurisdictions. Sacramento's code offers a model. Cities may wish to change their permitting system from annual to every other year or every five years given that city permits do not govern food safety nor finance food safety inspections.

The public health implications of creating a supportive working environment for the vendors could be further supported with city hookups for electricity to reduce noise and emissions associated with running a generator. Supportive built environment features, like public restrooms, would likely have health benefits beyond vendor populations, enabling clients to wash their hands before eating.

Even more supportive legislation could encourage the vending of healthy food through reduced fees or fast-track permitting for fresh produce, particularly in under-served areas. Additional financial and policy support for the street food model presents a relatively low-cost health intervention when compared to funding the construction of a new supermarket (Chrisinger, 2016). None of the regulations governed the type of food sold. Encouraging the sale of fresh fruits and vegetables or healthy food presents a unique public health intervention for cities to pilot.

\section{Broader Impacts}

Current restrictions dampen the potential for positive diet-related health outcomes associated with street food vending, and they block a healthy food access pathway common in lowincome communities. Because street food vending regulations are heavily focused on restricting access to clientele, we suspect that the primary rationale for the ordinances is to protect brick and mortar businesses from competition. Importantly, as cities and counties update street food vending codes, it will be important to keep regulations for mobile food vendors in line with restaurant regulations. For example, many California cities ban polystyrene take-out containers, those same restrictions should also apply to mobile businesses as well to limit unfair business advantages. 
We expect that improving street food vending regulations will open economic opportunities for vendors and nearby storeowners. Because health is tightly correlated to socioeconomic status (James et al., 1997), such impacts are expected to improve health more broadly. As spillover effects from farmers' markets have proved (Brown \& Miller, 2008), shoppers often spend more at nearby businesses on farmers market days, creating synergistic impacts on the local economy in tandem with brick and mortar stores. Economic evidence from Los Angeles, California suggests that street vendors play a complementary role to brick and mortar establishments, generating multiplier effects on the local economy by increasing foot traffic and shopping (Liu et al., 2015). Vending also opens new jobs and space for food entrepreneurship and innovation much like a business incubator. For example, mobile food vending offers opportunities for existing brick and mortar businesses to expand by testing new markets by operating pop-up stands or food trucks. Opening more opportunities for businesses can also increase tax revenues for the City through business permitting and sales.

\section{Limitations}

While focused on California, we believe our findings are well-supported elsewhere in the Global North. Prior studies outside of California also show that restrictions placed on street food vendors do not directly correlate with public health concerns and are more restrictive than regulations for brick and mortar food businesses.
For example, in West Philadelphia, Pennsylvania vendor's carts are restricted by cart size and they were prohibited from operating between the hours of midnight and 7am (Brinkley et al., 2013). In Dallas, Texas a vendor cannot stay more than three hours in one location (Calderon, 2015). More widely, Tester et al. (2012) find that municipal and public health codes prohibit vendors from selling near schools and parks in Phoenix, Arizona; San Antonio, Texas; San Diego, California; and San Jose, California.

\section{Conclusion}

The shift in street food policy presents researchers with an opportunity to investigate the effects of SB946's policy "intervention" and chart the resurgence of a naturally emergent practice and its impact on health. Previous research indicates that improving street food vending policy will allow vendors to operate more safely while also improving diet-related health through increasing the supply of low-cost fruits and vegetables and their consumption. Such policy changes open opportunities for pre/post- intervention studies on this prevalent small-scale pathway to healthy food access and the attending impact on diet-related health. The data provided in this research is immediately relevant to crafting ordinances and offers and an important touchstone in broader public health discourses on forming an equitable food system through both research and practice. 


\section{References}

Ababio, P. F., \& Lovatt, P. (2015). A review on food safety and food hygiene studies in Ghana. Food Control, 47, 92-97.

Abrahale, K., Sousa, S., Albuquerque, G., Padrão, P., \& Lunet, N. (2019). Street food research worldwide: A scoping review. Journal of Human Nutrition and Dietetics, 32(2), 152-174.

AbuSabha, R., Namjoshi, D., \& Klein, A. (2011). Increasing access and affordability of produce improves perceived consumption of vegetables in low-income seniors. Journal of the American Dietetic Association, 111(10), 1549-1555.

Auad, L. I., Ginani, V. C., dos Santos Leandro, E., Nunes, A. C. S., Junior, D., Pires, L. R., \& Zandonadi, R. P. (2018). Who is serving us? Food safety rules compliance among Brazilian food truck vendors. International Journal of Environmental Research and Public Health, 15(12), 2807.

Benach, J., Muntaner, C., Santana, V., \& Chairs, F. (2007). Employment conditions and health inequalities. Final report to the WHO Commission on Social Determinants of Health (CSDH) Employment Conditions Knowledge Network (EMCONET). Geneva: WHO.

Brata, A. G. (2010). Vulnerability of urban informal sector: street vendors in Yogyakarta, Indonesia. Theoretical and Empirical Researches in Urban Management, 5 (14), 47-58.

Breck, A., Kiszko, K. M., Abrams, C., \& Elbel, B. (2015). Peer reviewed: Spending at mobile fruit and vegetable carts and using SNAP benefits to pay, Bronx, New York, 2013 and 2014. Preventing Chronic Disease, 12.

Brinkley, C., Chrisinger, B., \& Hillier, A. (2013). Tradition of healthy food access in low-income neighborhoods: Price and variety of curbside produce vending compared to conventional retailers. Journal of Agriculture, Food Systems, and Community Development, 4(1), 155.

Brinkley, C., Glennie, C., Chrisinger, B., \& Flores, J. (2019). "If you Build it with them, they will come": What makes a supermarket intervention successful in a food desert? Journal of Public Affairs, e1863.

Brinkley, C., Raj, S., \& Horst, M. (2017). Culturing food deserts: Recognizing the power of communitybased solutions. Built Environment, 43(3), 328-342.

Brown, A. (2015). Claiming the streets: Property rights and legal empowerment in the urban informal economy. World Development, 76, 238-248.

Brown, C., \& Miller, S. (2008). The impacts of local markets: A review of research on farmers markets and community supported agriculture (CSA). American Journal of Agricultural Economics, 90(5), 1298-1302.

Calderon, K. B. (2015). Street mobile food vending: local policies, informality, and occupational health in immigrant communities (Doctoral dissertation, Arts and Letters).

Campos, J., Gil, J., Mourão, J., Peixe, L., \& Antunes, P. (2015). Ready-to-eat street-vended food as a potential vehicle of bacterial pathogens and antimicrobial resistance: An exploratory study in Porto region, Portugal. International Journal of Food Microbiology, 206, 1-6.

Chrisinger, B. W. (2016). Taking stock of new supermarkets in food deserts: Patterns in development, financing, and health promotion. Working paper (Center for Community Development Investments), 2016.

Davy, B. (2009). Centenary paper: The poor and the land: Poverty, property, planning. Town Planning Review, 80(3), 227-265.

Devlin, R. T. (2018). Asking 'Third World questions' of first world informality: Using southern theory to parse needs from desires in an analysis of informal urbanism of the global North. Planning Theory, 17(4), 568-587.

Devlin, R. T. (2011). 'An area that governs itself': Informality, uncertainty and the management of street vending in New York City. Planning Theory, 10(1), 53-65. 
Donkor, E., Kayang, B., Quaye, J., \& Akyeh, M. (2009). Application of the WHO keys of safer food to improve food handling practices of food vendors in a poor resource community in Ghana. International Journal of Environmental Research and Public Health, 6(11), 2833-2842.

Duedu, K. O., Yarnie, E. A., Tetteh-Quarcoo, P. B., Attah, S. K., Donkor, E. S., \& Ayeh-Kumi, P. F. (2014). A comparative survey of the prevalence of human parasites found in fresh vegetables sold in supermarkets and open-aired markets in Accra, Ghana. BMC Research Notes, 7(1), 836.

Economic Roundtable, The. n.d. "Economic and Geographical Impact of LA Street Vendors." http://economicrt.org/current-projects/economic-and-geographical-impact-of-la-street-vendors/

Ehrenfeucht, R. (2017). Do food trucks and pedestrians conflict on urban streets? Journal of Urban Design, 22(2), 273-290.

Eskenazi, J. (2012) 'Food Tax Flow Chart' SF Weekly. https://www.sfweekly.com/news/food-taxflowchart-will-you-be-taxed-on-your-to-go-purchase/ accessed: January 22, 2020

Esparza, N., Walker, E. T., \& Rossman, G. (2014). Trade associations and the legitimation of entrepreneurial movements: Collective action in the emerging gourmet food truck industry. Nonprofit and Voluntary Sector Quarterly, 43(2_suppl), 143S-162S.

Hernández-López, E. (2011). LA's taco truck war: How law cooks food culture contests. University of Miami Inter-American Law Review, 43, 233-268.

Holmes, M. R., Dodds, R., Deen, G., Lubana, A., Munson, J., \& Quigley, S. (2018). Local and organic food on wheels: exploring the use of local and organic food in the food truck industry. Journal of Foodservice Business Research, 21(5), 493-510.

IBIS (2020). Food Trucks Industry in the US - Market Research Report https://www.ibisworld.com/united-states/market-research-reports/food-trucks-industry/ accessed Jan 16, 2020.

James, W. P. T., Nelson, M., Ralph, A., \& Leather, S. (1997). Socioeconomic determinants of health: The contribution of nutrition to inequalities in health. British Medical Journal, 314(7093), 1545.

Kettles, G. W. (2004). Regulating vending in the sidewalk commons. Temple Law Review, 77, 1.

Kothe, C. I., Schild, C. H., Tondo, E. C., \& da Silva Malheiros, P. (2016). Microbiological contamination and evaluation of sanitary conditions of hot dog street vendors in Southern Brazil. Food Control, 62, 346-350.

Leggat, M., Kerker, B., Nonas, C., and Marcus, E. (2012). Pushing produce: The New York City green carts initiative. Journal of Urban Health: Bulletin of the New York Academy of Medicine, 89(6), 937.

Li, K. Y., Cromley, E. K., Fox, A. M., \& Horowitz, C. R. (2014). Peer reviewed: Evaluation of the placement of mobile fruit and vegetable vendors to alleviate food deserts in New York City. Preventing Chronic Disease, 11.

Linnekin, B. J., Dermer, J., \& Geller, M. (2012). The new food truck advocacy: Social media, Mobile food vending associations, truck lots, \& litigation in California and beyond. Nexus: A Journal of Opinion, 17, 35-58.

Liu, Y. Y., Burns, P., \& Flaming, D. (2015). Sidewalk Stimulus: Economic and Geographic Impacts of Los Angeles Street Vendors. Available at SSRN 3380029. Accessed: https://economicrt.org/publication/sidewalk-stimulus/ Oct 15, 2019

Lucan, S. C. (2015). Concerning limitations of food-environment research: A narrative review and commentary framed around obesity and diet-related diseases in youth. Journal of the Academy of Nutrition and Dietetics, 115(2), 205-212.

Lucan, S. C., Maroko, A. R., Bumol, J., Varona, M., Torrens, L., \& Schechter, C. B. (2014). Mobile food vendors in urban neighborhoods-Implications for diet and diet-related health by weather and season. Health \& Place, 27, 171-175. 
Lucan, S. C., Maroko, A., Shanker, R., \& Jordan, W. B. (2011). Green Carts (mobile produce vendors) in the Bronx-optimally positioned to meet neighborhood fruit-and-vegetable needs? Journal of Urban Health, 88(5), 977.

Martin, N. (2014). Food fight! Immigrant street vendors, gourmet food trucks and the differential valuation of creative producers in Chicago. International Journal of Urban and Regional Research, 38(5), 1867-1883.

Meneses-Reyes, R. (2018). (Un) Authorized: A study on the regulation of street vending in Latin America. Law \& Policy, 40(3), 286-315.

Murray, C.J., Abraham, J., Ali, M.K., Alvarado, M., Atkinson, C., Baddour, L.M., Bartels, D.H., Benjamin, E.J., Bhalla, K., Birbeck, G. and Bolliger, I. (2013). The state of US health, 19902010: Burden of diseases, injuries, and risk factors. Journal of the American Medical Association, 310(6), 591-606.occupational health of women street vendors in Johannesburg, South Africa," Social occupational health of women street vendors in Johannesburg, South Africa," Social

Okumus, B., \& Sonmez, S. (2019). An analysis on current food regulations for and inspection challenges of street food: Case of Florida. Journal of Culinary Science \& Technology, 17(3), 209-223.

Pick, W. M., Ross, M. H., \& Dada, Y. (2002). The reproductive and occupational health of women street vendors in Johannesburg, South Africa. Social Science \& Medicine, 54(2), 193-204.

Qadri, R. (2017). Vending the city: Mapping the policy, positioning and policing of vending in New York City. In International Conference on Computers in Urban Planning and Urban Management (pp. 419-431). Springer, Cham.

Roever, S. (2016). Informal trade meets informal governance: Street vendors and legal reform in India, South Africa, and Peru. Cityscape, 18(1), 27-46.

Rubinstein, G. H. (2018). The Arabbers and their horses: Reconciling animal welfare concerns and African American tradition to benefit Baltimore City. Mid-Atlantic Journal of Law and Public Policy, 4, 177.

Shin, Y. H., Kim, H., \& Severt, K. (2018). Antecedents of consumers' intention to visit food trucks. Journal of Foodservice Business Research, 21(3), 239-256.

Tester, J. M., Yen, I. H., \& Laraia, B. (2012). Peer reviewed: Using mobile fruit vendors to increase access to fresh fruit and vegetables for schoolchildren. Preventing Chronic Disease, 9.

Valente, G. M., Stangarlin-Fiori, L., de Oliveira Seiscentos, L., de Souza, V. V., \& Medeiros, C. O. (2019). Profile of food truck consumers and their opinion about food safety. Nutrition \& Food Science.

Vanschaik, B., \& Tuttle, J. L. (2014). Mobile food trucks: California EHS-Net study on risk factors and inspection challenges. Journal of Environmental Health, 76(8), 36-38.

Weber, D. (2012). The Food truck handbook: Start, grow, and succeed in the mobile food business. Hoboken, NJ: John Wiley.

Webster, C. (2015). Property Rights, Public Space and Urban Design, Town Planning Review, 78, 81101.

World Health Organization - WHO Essential safety requirements for street-vended foods. Revised version Food Safety Unit: World Health Organization (1996)

Wright, K., \& Anderson, L. (2014). Peer reviewed: Comparing apples to oranges: Comparative case study of 2 produce carts in Chicago. Preventing Chronic Disease, 11.

Yasmeen, G. (2001). Stockbrokers turned sandwich vendors: the economic crisis and small-scale food retailing in Southeast Asia. Geoforum, 32(1), 91-102.

Zepeda, L., Reznickova, A., \& Lohr, L. (2014). Overcoming challenges to effectiveness of mobile markets in US food deserts. Appetite, 79, 58-67. 
Corresponding Author Information

Dr. Catherine Brinkley, Ph. D. (ORCID: 0000-0002-3642-8207) Associate Professor, Department of Human Ecology, Community and Regional Development University of California, Davis 1 Shields Avenue, 2333 Hart Hall Davis, California 95616

Tel: 267-252-2289

Email: ckbrinkley@ucdavis.edu 